4 | 1985

Aspects des agricultures insolites de l'Amérique indienne

\title{
Un agave textile, le zapupe : travail agricole et production artisanale chez les Huastèques
}

Jesus Ruvalcaba

\section{(2) OpenEdition \\ Journals}

Édition électronique

URL : https://journals.openedition.org/tc/986

DOI : $10.4000 /$ tc. 986

ISSN : 1952-420X

Éditeur

Éditions de l'EHESS

Édition imprimée

Date de publication : 1 février 1985

ISSN : 0248-6016

Référence électronique

Jesus Ruvalcaba, « Un agave textile, le zapupe : travail agricole et production artisanale chez les

Huastèques », Techniques \& Culture [En ligne], 4 | 1985, mis en ligne le 26 janvier 2006, consulté le 29 septembre 2022. URL : http://journals.openedition.org/tc/986 ; DOI : https://doi.org/10.4000/tc.986

Ce document a été généré automatiquement le 29 septembre 2022.

Tous droits réservés 


\section{Un agave textile, le zapupe : travail agricole et production artisanale chez les Huastèques}

Jesus Ruvalcaba 